THEORIES OF

MODERN ART 



\section{THEORIES OF}

\section{MODERN ART}

A Source Book

by Artists and

Critics

\section{HERSCHEL B. CHIPP}

contributions by

PETER SELZ and JOSHUA C. TAYLOR 
University of California Press, Berkeley and Los Angeles, California University of California Press, Ltd., London, England Theories of Modem Art is a volume in the CALIFORNIA STUDIES IN THE HISTORY OF ART sponsored in part by the Samuel H. Kress Foundation Copyright $\odot 1968$ by The Regents of the University of California (c) Renewed 1996 Heide Chipp ISBN 0-520-05256-0

Library of Congress Catalog Card Number 68-12038

Printed in the United States of America

$\begin{array}{lllllll}12 & 11 & 10 & 09 & 08 & 07 & 05\end{array}$

$\begin{array}{lllllll}32 & 31 & 30 & 29 & 28 & 27 & 26\end{array}$

The paper used in this publication meets the minimum requirements of ANSI/NISO Z39.48-1992 (R 1997) (Permanence of Paper). () 